\title{
Régimen patrimonial del matrimonio: contexto histórico que rodeó la promulgación de la Ley 28 de $1932^{*}$
}

\author{
Matrimonial Property System: Historical Context Surrounding \\ the Enactment of the Law 28 of 1932 \\ Régime patrimonial do casamento: contexto histórico que rodeou \\ a promulgação da Lei 28 de 1932
}

\section{Paola Marcela Gómez Molina*}

FECHA DE RECEPCIÓN: 4 DE JUNIO DE 2014. FECHA DE ACEPTACIÓN: 6 DE OCTUBRE DE 2014

Doi: dx.doi.org/10.12804/esj 17.01.2014.02

Cómo citar este artículo: Gómez Molina, P. M. (2015). Régimen patrimonial del matrimonio: contexto histórico que rodeó la promulgación de la Ley 28 de 1932. Estudios Socio-Jurídicos, 17(1), 41-76. Doi: dx.doi.org/10.12804/esj17.01.2014.02

\section{RESUMEN}

Este artículo presenta los resultados de la investigación que buscó reconstruir el contexto histórico de la promulgación de la Ley 28 de 1932, que reformó la situación jurídica de incapacidad civil de las mujeres casadas. Antes de esta reforma, las mujeres casadas colombianas eran jurídicamente incapaces, esto es, no tenían autonomía para realizar ningún acto jurídico como celebrar un contrato y eran tratadas igual que los menores de edad y los dementes. Con la reforma, la mujer casada adquirió plena capacidad civil en igual de condiciones que su esposo y las mujeres mayores de edad solteras. Mediante la revisión y análisis de fuentes primarias como los Anales del Senado y la Cámara de Representantes del Congreso de Colombia de los años 1930 a 1932 y de la prensa de la misma época, se estableció el gran esfuerzo que el gobierno del presidente Olaya Herrera tuvo que hacer para superar la resistencia del Congreso de la República a reformar las normas que negaban los derechos civiles y económicos de las mujeres casadas. Así mismo, se estableció que hubo participación femenina

* Artículo resultado del proyecto de investigación titulado La influencia de la crítica feminista al matrimonio y a su régimen patrimonial: un estudio de los contextos históricos de las reformas legales que establecieron los regímenes patrimoniales actuales en México, Chile y Colombia, iniciado en agosto de 2012 y financiado por la Facultad de Derecho y Vicerrectoría de Investigaciones y Doctorados de la Universidad de los Andes.

** Abogada y especialista en Instituciones Jurídico-Procesales de la Universidad Nacional de Colombia. Máster en Derecho de la Universidad de los Andes. Docente de la cátedra de Relaciones Familiares, miembro del grupo de investigación en Derecho y Género, y candidata a doctora en Derecho de la Universidad de los Andes, Facultad de Derecho, Bogotá, Colombia. Correo electrónico: pm.gomez10@uniandes.edu.co 
en los debates del Congreso, impulsada por el activismo en las calles de algunas mujeres que venían reclamando el reconocimiento de su capacidad civil. Por último, se estableció que la reforma de la Ley 28, que constaba tan solo de 10 artículos, hizo parte de un proyecto político más grande del presidente Olaya Herrera que pretendía impulsar a Colombia hacia lo que él denominaba una sociedad más "moderna".

Palabras clave: Régimen patrimonial del matrimonio, movimientos sociales de mujeres, república liberal, capacidad civil de las mujeres casadas.

\section{ABSTRACT}

This paper summarizes the results of a research about the reconstruction of the historical context where the Law 28 of 1932, which reformed the rules about matrimonial property system, was enactment. Before this reform, Colombian married women were legally incompetent, meaning that they were treated like children or insane people, having no faculty to make legal acts such as signing a contract. With the reform of 1932, married women obtained completely legal capacity in the same conditions of their husbands and adult single women. Through a revision and analysis of primary sources such as The Annals of Senate and the House of Representative of The Congress of Colombia from 1930 to 1932, and the newspaper of the same period, it was established the favorable political position of the Government of President Enrique Olaya Herrera about the recognition of married women civil and economics rights, as they were already recognized, at that time, to other married women in different European and Latin American countries like Italy, German, French and Ecuador, among many others. Also, it was established the female participation in Congress debates, which was driven by the activism of some women in the streets who were demanding the recognition of their civil rights. Finally, it was founded that the reform of the law number 28 of 1932, which only has 10 articles, was part of the biggest political project of President Olaya Herrera who pretended to push Colombia to what he named a "more modern society".

Key words: Matrimonial property system, women's social movements, liberal republic, married women's civil rights.

\section{RESUMO}

Este artigo apresenta os resultados da pesquisa que buscou reconstruir o contexto histórico da promulgação da lei 28 de 1932, que reformou a situação jurídica de incapacidade civil das mulheres casadas. Antes desta reforma, as mulheres casadas colombianas eram juridicamente incapazes, isto é, que não tinha autonomia para realizar nenhum ato jurídico como celebrar um contrato; eram tratadas igual que os menores de idade e os dementes. Com a reforma, a mulher casada adquiriu plena capacidade civil em igual condições que seu marido e as mulheres maiores de idade solteiras. Mediante a revisão e análise de fontes primárias como os Anais do Senado e a Câmara de Representantes do Congresso da Colômbia dos anos 1930 a 1932 e dos jornais da mesma época, se estabeleceu o grande esforço que o governo do Presidente Olaya Herrera teve que fazer para superar a resistência do Congresso da República a reformar as normas que negavam os direitos civis e económicos das mulheres casadas. Igualmente, se estabeleceu que houve participação feminina nos debates do Congresso, impulsada pelo ativismo nas ruas de algumas mulheres que vinham reclamando o reconhecimento de seus direitos civis. Por último, estabeleceu-se que a reforma da lei 28, que constava tão só de 10 artigos, fez parte de um projeto político maior do Presidente Olaya Herrera que pretendia impulsar à Colômbia ao que ele denominava uma sociedade mais "moderna".

Palavras-chave: Régime patrimonial do casamento, movimentos sociais de mulheres, república liberal, direitos civis das mulheres casadas. 


\section{Introducción}

En Colombia, cuando se adoptó la codificación civil para finales del siglo XIX, se estableció en el artículo 1771 y hacia delante el régimen económico patrimonial del matrimonio, que era una comunidad universal compleja compuesta por los bienes y gananciales de ambos esposos (Valencia Zea, 1970, p. 184). Además, en los artículos 1805 y 1806 de tal codificación se estableció que el marido administraría libremente esos bienes, que son los bienes propios tanto de él como de su esposa y los bienes comunes (Código Civil colombiano, 1887). Por último, en los artículos 177 y siguientes de la misma codificación se ordenó que la capacidad de las mujeres para disponer y administrar sus propios bienes desaparecía en el momento de contraer matrimonio y que, como persona, quedaba reducida su capacidad a la que tenían los menores de edad o los dementes (Código Civil colombiano, 1887). El esposo, entonces, tenía la autoridad absoluta de vender, por ejemplo, el carro de su esposa sin el consentimiento de aquella. En otras palabras, con la adopción del Código Civil, mediante la Ley 57 de 1887, se instituyó en Colombia un régimen patrimonial del matrimonio único que permitía al hombre administrar libremente todos los bienes del matrimonio y tratar a las mujeres casadas como si fueran niñas o interdictas, lo que implantó una distribución de poderes desproporcionada dentro del matrimonio que, además, condenaba a la esposa a una situación de desigualdad y opresión frente al marido.

Desde la vigencia de la mencionada Ley 57 de 1887, ese régimen económico del matrimonio de comunidad universal se mantuvo en Colombia. Solo hasta principios de la década de los treinta, dentro del contexto político de finalización de la Hegemonía Conservadora y el inicio de la República Liberal, se cuestionaron por primera vez los artículos del Código Civil que lo reglamentaban. El gobierno del presidente Enrique Olaya Herrera presentó ante el Congreso el proyecto de ley que luego se convirtió en la Ley 28 de 1932 sobre reformas civiles -régimen patrimonial en el matrimonio- (Anales de la Cámara de Representantes [ACR], sesiones ordinarias de 1932 , serie $1^{a},{ }^{a} .^{\circ} 18$, p. 86). Varios representantes y senadores de la legislatura que permanecieron desde 1931 hasta 1935 en el Congreso, así como algunas mujeres activistas que luchaban por obtener el reconocimiento de su capacidad civil, provenientes de diferentes regiones del país, 
fueron afines al proyecto presentado por el gobierno. De esta forma, se creó un ambiente de cambio hacia una sociedad que el gobierno de Olaya Herrera denominaba "moderna", como propuesta política de la República Liberal, que buscaba reorientar las políticas públicas hacia la construcción de una sociedad "civilizada y progresista" a la altura de los países más adelantados socialmente (ACR, sesiones extraordinarias de 1932, serie $1^{\text {a }}$, n. ${ }^{\circ} 18$, pp. 88 y 89 ).

Con la promulgación de la Ley 28 de 1932 la situación jurídica de la mujer casada y mayor de edad cambió. La ley le confirió a esta la plena capacidad civil, judicial y extrajudicial que le permitió disponer y administrar libremente de todos los bienes matrimoniales o, por lo menos, de los de su propiedad. Se le quitó así al esposo la autoridad absoluta sobre el patrimonio que ambos esposos aportaban al matrimonio o que adquirían como fruto de su trabajo durante este e intentó equilibrar de esta forma la distribución de poderes tan desproporcionada que existía entre los cónyuges dentro del matrimonio. ${ }^{1}$

La mayoría de los doctrinantes de derecho de familia e historiadores del derecho han estudiado esa reforma de 1932 como una respuesta a las necesidades de la familia en su función de unidad fundamental de la sociedad y en pro a su mantenimiento; pero no la ha estudiado en relación con las necesidades individuales de los miembros que la componen, uno de ellos: la mujer. Por el contrario, la teoría feminista ha entendido y teorizado sobre las relaciones de poder entre hombres y mujeres, tomados como individuos independientes dentro de la familia, y ha encontrado problemática la concepción jurídica de la propiedad de la mujer dentro del régimen patrimonial del matrimonio y que queda establecida en la ley. En este contexto, resulta importante estudiar el contexto histórico que rodeó la promulgación de la Ley 28 de 1932, teniendo en cuenta no solo

1 Otros textos relevantes para la discusión de los derechos de propiedad y la capacidad civil de las mujeres son: "¿Ruptura de la inequidad?: propiedad y género en la América Latina del siglo XIX", de Magdalena León y Eugenia Rodríguez; "Derecho y familia en Colombia: historias de raza, género y propiedad", de Isabel Cristina Jaramillo; "Married Women’s Property Rights as Human Rights: The Latin America Contribution", de Carmen Diana Deere; "Sexualidad y matrimonio en la América hispánica: siglos XVI-XVIII", de Asunción Lavrín; “Matrimonial Property: A Comparative Study of Law and Social Change", de Mary Ann Glendon, entre otros. Sin embargo, en este artículo no se aborda tal discusión, por cuanto lo que se busca es aportar a la historia del derecho en relación con la capacidad civil de la mujer. 
la descripción jurídica de un ambiente propio masculino como lo era el Congreso de 1930, sino también la descripción política donde hubo una importante participación femenina, por cuanto esta mirada nos permite, por un lado, profundizar nuestro conocimiento sobre la agenda de las feministas colombianas, en el sentido de conocer si las demandas feministas han permeado las reformas legales $\mathrm{y}$, por el otro, enriquecer el entendimiento de las estructuras jurídicas que forman nuestra sociedad.

Por ello, en el presente artículo se muestra el contexto jurídico y político del recorrido que la Ley 28 de 1932, que reformó el régimen patrimonial de matrimonio y transitó hasta lograr su promulgación. Se describe la contienda que el gobierno del presidente Olaya Herrera enfrentó de cara a la resistencia de algunos miembros del Congreso de la República al reconocimiento de la capacidad civil de las mujeres casadas. Así mismo, describe la participación femenina, en el Congreso y en las calles, que acompañó tal reforma. Por último, da cuenta de cómo esta ley fue parte de un proyecto más ambicioso de la República Liberal que el presidente Olaya Herrera denominaba "de modernización de la sociedad colombiana". Para ello, primero se presenta la situación jurídica en la que se encontraba la mujer casada con respecto a su esposo antes de la vigencia de la Ley 28 de 1932. Segundo, se describe el contexto político y social que rodeaban los debates en el Congreso frente a la propuesta de mejorar los derechos de las mujeres, en especial frente a su situación civil y económica. Tercero, se cuenta cuál y cómo fue la participación femenina en el ambiente social y político en el que se debatía tal propuesta sobre los derechos de las mujeres. Finalmente, se detallan los debates decisivos que determinaron la promulgación de la Ley 28 de 1932.

\section{Metodología}

Este artículo siguió un método histórico basado en fuentes primarias. Se revisaron los Anales de la Cámara de Representantes y del Senado de la República de los años 1930 a 1932 que reposan en medio físico en el archivo legislativo del Congreso de la República de Colombia. En la Biblioteca Nacional se revisó el archivo de prensa de circulación nacional de 1930 a 1932 y solamente se encontraron publicaciones en los diarios $E l$ 
Tiempo y El Espectador. Con el diario El Colombiano se determinó que empezó a publicarse desde 1912, pero tanto en la Biblioteca Nacional como en la Biblioteca Luis Ángel Arango solo lo registran desde 1947. Con la Gaceta Liberal se estableció que tuvo publicaciones desde 1908 a 1919. Y con respecto al diario El Liberal se encontró que tiene un salto de 1918 a 1938. Finalmente, se buscaron y revisaron las revistas feministas de la década de los treinta, pero no se encontró ningún ejemplar útil para el presente artículo. Por ejemplo, la revista Atenea sacó su primer volumen en 1933 y Hogar y Patria comenzó sus publicaciones en 1935. De la revista Alboradas no se tiene ninguna existencia ni en la Biblioteca Nacional ni en la Luis Ángel Arango, y con respecto a la revista Letras y Encajes se encontraron dos volúmenes en la Biblioteca Luis Ángel Arango de enero y junio de 1932, pero no contenía información relativa al tema de este trabajo.

\section{La situación de la mujer casada antes de la promulgación de la Ley 28 de 1932}

El 12 de noviembre de 1932, bajo el gobierno de Enrique Olaya Herrera, el Congreso de la República aprobó la Ley 28, que modificó el régimen económico matrimonial de la sociedad conyugal y, con ella, la capacidad civil de la mujer casada en Colombia. Fue el quinto de cuatro proyectos de ley presentados con el fin de mejorar la situación de desigualdad de la mujer casada.

El primer proyecto se presentó el 20 de agosto de 1930 ante la legislatura de la Cámara de Representantes, que terminaba su periodo el 20 de julio de 1931. Esto es, se presentó frente a una legislatura saliente, ya que cumplía su último periodo. Tal proyecto fue presentado por el ministro de Gobierno de entonces, Carlos E. Restrepo, bajo el nombre "Proyecto de ley reformatorio del Código Civil". Buscaba la reforma de los artículos 1771, 1776, 1778, 1779 y 200 del Código Civil colombiano para que se reformara la institución de las capitulaciones matrimoniales, en el sentido de que pasara a ser una convención que pudieran celebrar los esposos no solo antes de contraer matrimonio, sino también después de que se hubiera contraído (ACR, sesiones ordinarias de 1930, serie $1^{a}{ }^{a}$, n. ${ }^{\circ}$ 1, p. 248). Este proyecto fue archivado. Posteriormente, el mismo proyecto, pero con algunas 
ligeras modificaciones, fue nuevamente presentado un año después y es el tercer proyecto de los cuatro a los que hago referencia. No obstante, es un proyecto de reforma independiente al anterior, porque en esta oportunidad fue presentado ante el Senado de la República. Además, porque cuando el senador Mario Fernández de Soto lo presentó, el 31 de julio de 1931, señaló que el anterior proyecto, esto es, el presentado ante la legislatura saliente de la Cámara de Representantes en agosto de 1930, "no alcanzó a ser ley de la República porque el legislador del año 30 se dedicó preferentemente al estudio de otros asuntos no menos graves e importantes" (ACR, sesiones ordinarias de 1931, serie $1^{a},{ }^{a}$ n. ${ }^{\circ} 11$, p. 74 ). Este tercer proyecto de los cuatro referenciados también fue archivado. El segundo proyecto fue presentado el 9 de octubre de 1930 ante la legislatura de la Cámara de Representantes bajo el nombre de "Proyecto de ley sobre reformas civiles". Tres miembros de la Comisión de Legislación Civil, representantes Alberto Suárez Murillo, Fernando Botero A. y Miguel Gómez Fernández, redactaron y presentaron dicha reforma encaminada a adicionar los artículos 303, 483 y 1810 del Código Civil para que quedara restringida la enajenación que pudiera hacer el marido de los derechos hereditarios de la esposa a la autorización del juez (ACR, sesiones ordinarias de 1930, serie $1^{\mathrm{a}}{ }^{\mathrm{a}} \mathrm{n} .^{\mathrm{o}} 1$, p. 522). Este proyecto se convirtió en la Ley 67 de 1930. El cuarto proyecto se presentó el 22 de septiembre de 1931 ante el Senado de la República bajo el nombre de "Proyecto de ley sobre derechos de la mujer". El senador Absalón Fernández de Soto redactó y presentó un proyecto de mayor alcance que plasmara el "moderno principio de la igualdad jurídica de los sexos" en todos nuestros códigos (ACR, sesiones ordinarias de 1931, serie 3, n. 54 y 55, p. 377). Este cuarto proyecto también fue archivado.

Finalmente, se aprobó el quinto proyecto llamado "Proyecto de ley sobre reformas civiles-régimen patrimonial en el matrimonio", presentado el 7 de julio de 1932 ante la Cámara de Representantes por los ministros de Gobierno, Agustín Morales Olaya; de Hacienda, Esteban Jaramillo, y de Industria, Francisco José Chaux (ACR, sesiones ordinarias de 1932, serie $1^{\text {a }}$, n. ${ }^{\circ} 18$, p. 87). Este proyecto, convertido en la Ley 28 de 1932, derogó y subrogó los artículos del Código Civil que sostenían los principios de la incapacidad civil de la mujer y de la universalidad del régimen económico 
matrimonial. ${ }^{2}$ Con su sanción y promulgación, comenzó un largo camino de reformas jurídicas - que aún no termina- hacia el reconocimiento normativo de los derechos de la mujer en Colombia.

La situación de la mujer casada se encontraba regulada por los artículos 177 hasta el 211 del Código Civil, que en su conjunto establecían varios límites a la capacidad civil de la mujer por efecto del acto del matrimonio. Estos límites eran: 1) la potestad marital, que consistía en el conjunto de derechos que las leyes le concedían al marido sobre la persona y los bienes de la esposa. 2) La toma por parte del marido de la administración de los bienes de su esposa como un derecho adquirido por el acto del matrimonio. 3) La incapacidad para comparecer a juicio por sí misma o por procurador sin la autorización escrita de su marido. 4) La imposibilidad legal de ella para celebrar contrato alguno, o de desistir de uno anterior, o de aceptar o repudiar una donación, herencia o legado sin la autorización del marido. 5) La incapacidad de ejercer públicamente una profesión o industria cualquiera sin la autorización del marido. 6) La posibilidad de que el marido pidiera judicialmente la terminación de la separación de bienes decretada por un juez por solicitud de la mujer. 7) Además, el artículo 1791 establecía la obligación de obtener por parte de la mujer previa licencia del juez para subrogar sus bienes. 8) Finalmente, el artículo 1504 establecía taxativamente que eran incapaces las mujeres casadas, aunque su incapacidad no era absoluta, ya que sus actos podían tener valor en ciertas circunstancias y bajo ciertos respectos determinados por la ley (Torres, 1970, pp. 123-133, 636 y 789).

Más adelante en el mismo Código Civil, los artículos 1805 y siguientes establecían el régimen patrimonial antiguo llamado régimen de universalidad. Consistía en la formación de una comunidad de bienes similar a la de la sociedad conyugal que conocemos hoy, pero a la que ingresan todos los bienes muebles e inmuebles que los cónyuges aportan al matrimonio y que durante este adquieran, exceptuándose los aportes y las adquisiciones a título gratuito y administrada exclusivamente por el marido. Por

2 Para un análisis más detallado de la naturaleza jurídica de la sociedad conyugal con la Ley 28 de 1932 se pueden consultar los textos de Arturo Valencia Zea, Derecho de familia (tomo V); Marco Gerardo Monroy Cabra, Derecho de familia y de menores; Pedro Lafont Pianetta, Derecho de familia (tomo II); Jorge Parra Benítez, Derecho de familia; Roberto Suárez Franco, Derecho de familia (tomo I), entre otros manuales de derecho de familia. 
efecto de esta exclusividad, el administrador tenía la facultad de adquirir la calidad de dueño de los bienes sociales ante terceros. De esta manera, durante la vigencia de la sociedad conyugal, los bienes propios del marido y los aportados por ambos a la sociedad formaban un solo patrimonio que los acreedores del marido podían perseguir, sin distinguir entre los bienes de este y los de la esposa. Además, el marido era también el jefe de la sociedad conyugal, lo que significaba que administraba libremente no solo sus bienes propios y los de la sociedad conyugal, sino los bienes propios de la esposa, sujeto solamente a las restricciones de la ley o las impuestas en capitulaciones matrimoniales, si las había. Finalmente, el artículo 1808 hacía hincapié en que la mujer, por sí sola, no tenía derecho alguno sobre los bienes sociales; por lo tanto, no podía administrarlos, ni controlar en ninguna forma la sociedad conyugal y tampoco podía solicitar la entrega de la parte que de ellos le pertenecía mientras la sociedad existiera (Torres, 1970, pp. 1262 y 1263). ${ }^{3}$

\section{Contexto político}

\subsection{Posición del gobierno de Enrique Olaya Herrera frente a los derechos de la mujer}

A partir del contexto jurídico presentado, la situación de la mujer casada en la década de los treinta era considera por el gobierno del presidente Olaya Herrera un estado injusto y degradante. Además de marginar a la mujer colombiana, no correspondía a una sociedad que su gobierno denominaba moderna, pues no coincidía con la tendencia universal de aquel entonces de emancipación económica de la mujer y el reconocimiento de su capacidad civil. El mismo presidente Olaya, quien fue el primer presidente de la llamada República Liberal después de la denominada Hegemonía Conservadora, mediante un mensaje dirigido a las cámaras legislativas, en 1931, anunció esta como su posición política frente al reconocimiento de los derechos de la mujer:

3 Para mayor claridad véase anexo 1. 
Nuestro estatuto civil merece ser revisado en todo lo referente a la situación jurídica de la mujer casada, especialmente en cuanto toca con su estado patrimonial. Es aberrante la inferioridad artificial en que nuestras instituciones colocan a la mujer, que siendo plenamente capaz antes de su matrimonio, deja de serlo apenas se casa. Al último congreso presentó el Ministro de Gobierno un proyecto de ley [...] encaminado a facilitar la separación voluntaria de bienes y el otorgamiento de capitulaciones matrimoniales después del matrimonio; medidas que [...] están respaldadas por la justicia, la equidad, las conveniencias sociales y las normas de los códigos más modernos y sabidos, como el alemán y el suizo. ${ }^{4}$

El abogado consultor de la Presidencia de la República Luis Felipe Latorre, frente a la legislatura de la Cámara de Representantes de 1932, defendió el "Proyecto de ley sobre reformas civiles-régimen patrimonial en el matrimonio", que fue el nombre del proyecto que finalmente se convirtió en la Ley 28. En la exposición de motivos señaló la nueva política del gobierno liberal en el que la mujer colombiana debía tener libertad de disponer de sus propios bienes porque, en pocas palabras, en otros países más "modernos" que Colombia así se había establecido desde hace algunas décadas atrás. En su discurso argumentó lo siguiente:

En una forma u otra, casi todos los países han ido otorgando a la mujer mayores garantías, más independencia, más medios defensivos, etc.

La ley italiana del 17 de julio de 1919 abolió las restricciones a la capacidad de la mujer casada, quien puede actualmente disponer de sus bienes con toda libertad y sin control alguno [...]

En Alemania, el contrato de matrimonio puede hacerse antes o después de este, modificarse en cualquier tiempo y con toda libertad [...] De los mismos bienes puede disponer con toda libertad la mujer casada, cuya incapacidad desapareció con el Código alemán de 1900.

El Código Civil suizo de 1907 consagra, en su artículo 179, el derecho de celebrar el contrato de matrimonio antes o después de este, pudiendo así modificarse el régimen matrimonial en cualquier tiempo. 
La leyes francesas de 1907 y 1919 establecen que [...] la mujer tiene sobre los productos de su trabajo personal y sobre las economías que provengan de él, los derechos de administración y de disposición a título oneroso [...]

En los Países Bajos, la mujer casada puede disponer libremente de su salario, conforme a una ley de 1907.

En Austria, los bienes no constituidos en dote forman el patrimonio personal de la mujer, la cual goza de la libre administración y disposición.

En Rumania, por virtud de una ley sobre el contrato del trabajo, la mujer casada goza de entera capacidad para contratar [...] y puede disponer con entera libertad no solamente de su salario, sino también de todas las economías y adquisiciones que provengan de él.

En Inglaterra [...] la mujer casada goza de plenos poderes sobre su patrimonio personal [...]

En los Estados Unidos la mujer casada goza de la plena capacidad civil.

En el moderno Código de la República Turca [...] la mujer que ejerce una profesión lucrativa tiene el derecho de ejecutar todos los actos inherentes a su ejercicio [...]

En Hungría [...] las costumbres y la legislación desconocen el poder marital y las desigualdades entre los esposos. La incapacidad jurídica de la mujer no existe.

[...]

Si a la reseña precedente se añaden las modernas instituciones citadas al principio, de países como Suecia, Finlandia, Noruega, Dinamarca y Finlandia [sic], se comprenderá cómo no es posible que Colombia se sustraiga al movimiento universal contemporáneo, que persigue la emancipación económica de la mujer y el reconocimiento de su capacidad civil, sin que esto haya ocasionado en ninguna parte del mundo los trastornos que aquí se han tenido y que no podrían producirse sino en el supuesto inadmisible de que las mujeres colombianas fueran inferiores intelectual y moralmente a las de todos los países de la tierra en donde se les han otorgado aquellos derechos.

Es de creerse que el Congreso de 1932, que vendrá inspirado en las más altas ideas de civilización y progreso, sabrá dar buena acogida al proyecto de ley en referencia (ACR, sesiones extraordinarias de 1932, serie $1^{\mathrm{a}}$, n. ${ }^{\circ} 18$, p. 74 ). 


\subsection{El desarrollo del ambiente político en el Congreso: algunos congresistas y mujeres activistas ayudan a crear el ambiente para la aprobación del proyecto de ley}

El Congreso de la República comenzó una nueva legislatura el 20 de julio de 1931. Ante el nuevo Senado se presentaron varios proyectos tendientes a reformar numerosos artículos del Código Civil relacionados con los derechos de la mujer. Aunque ninguno de estos proyectos llegó a ser ley de la República, los debates que se llevaron a cabo alrededor de cada uno de ellos sirvieron para crear el ambiente político que dio vida a la Ley 28 de 1932. Paralelamente, los movimientos de mujeres que luchaban por sus derechos se movían por fuera del Congreso para buscar presionar la aprobación del proyecto que sería la mencionada Ley 28. Estas mujeres, a través de activismo político, despertaron en la sociedad un interés por la reivindicación de los derechos civiles y económicos de la mujer casada, y en algunos congresistas, afinidad por sus ideas.

En el discurso de la exposición de motivos del "Proyecto de ley para reformar el régimen de capitulaciones matrimoniales", presentado por segunda vez, pero ahora ante el Senado de la República, el senador Mario Fernández de Soto criticó el criterio jurídico que regía para aquel entonces en el Código Civil de considerar a la mujer casada inferior al hombre, por cuanto este era un criterio muy antiguo que pasaba por alto el orden social moderno. Explicó en su discurso que:

Dos criterios jurídicos se enfrentan en la discusión de este proyecto: el que mantiene el principio de que en Colombia, de acuerdo con lo establecido en el artículo 177 de Código Civil, la persona y bienes de la mujer casada quedan bajo la potestad del marido, y el criterio que inspira la iniciativa que os presento en virtud del cual se extingue la injusticia secular de considerar a la mujer casada como una persona inferior al hombre en orden a la adquisición y ejercicio de derechos sobre los bienes materiales, y aun por concepto del factor espiritual, moral e intelectual, solo por el hecho de haber contraído matrimonio. De la aplicación de uno u otro criterio surgió en la legislación civil la necesidad de adoptar sistemas legales diferentes.

El criterio de la inferioridad jurídica de la mujer casada dio origen al cuerpo de doctrina consignado en el Código de Napoleón, reminiscencia 
natural y lógica de una organización social en la que el varón lo era todo, así en las artes de la guerra como en las de la creación de la riqueza, en las del estudio y en las de la ciencia.

[...]

En la época actual, especialmente en el orden social creado después de la guerra europea, la mujer ha llegado a ser factor de acción y reacción, porque el desarrollo intelectual y hasta físico de las generaciones femeninas, la extensión de su personalidad como fuerza moral y social, y una más noble y completa percepción de sus deberes y derechos dentro del estado civil y político, la capacitan ampliamente para sumarse a las fuerzas realmente constructivas de una sociedad que es todo cooperación, armonía, método y orden entre sus distintos componentes.

Ignorar esta saludable evolución y permitir que la mujer casada siga siendo entre nosotros la presa codiciada de los cazadores de dotes, o la víctima resignada del vicio o de la incapacidad de su marido, es una injusticia que los legisladores colombianos debemos corregir con nobilísimo espíritu, exento de egoísmos oscuros y tortuosos (ACR, sesiones ordinarias de 1931 , serie $1^{\mathrm{a}},{ }^{\mathrm{o}}{ }^{\circ} 11$, p. 74$)$.

En la exposición de motivos del "Proyecto de ley sobre derechos de la mujer", proyecto que aunque no se debatió por la legislatura del Senado de 1931, ni se convirtió en ley de la República, fue defendida enérgicamente por el senador Absalón Fernández de Soto la importancia para Colombia de permear toda la ley escrita con el principio de igualdad jurídica entre hombres y mujeres y no solamente en la normatividad que regula las libertades de quienes contraen matrimonio, con el fin de ponernos en sintonía con la tendencia occidental que se vivía en la época frente al reconocimiento de la igualdad de géneros. Al respecto dijo en su discurso que:

El moderno principio de la igualdad jurídica de los sexos es cuestión que -inclusive en Colombia- ya nadie se atreve a discutir. Sin embargo, por indolencia o por no convenir a nuestros intereses egoístas, no nos hemos querido tomar la molestia de revisar nuestros Códigos, para eliminar de ellos los errores y preceptos que contienen contra la mujer, fundamentalmente contrarios a aquella noción elemental de justicia y humanidad.

[...]

Todos los años dictamos, o pugnamos porque dicten leyes enderezadas a perfeccionar nuestras instituciones políticas y civiles. Nada más loable. 
Solo que nos preocupamos de las que interesan al hombre, pues en pinto de protección a la mujer, y reconocimiento de lo que en justicia le corresponde, iqué leves y tímidos han sido los esfuerzos hasta ahora realizados!

[...]

Y en tanto que en Colombia retardamos indefinidamente la revisión de las leyes que regulan la capacidad jurídica de la mujer, de otros países jóvenes, de tradición, idioma, religión y costumbres iguales a las nuestras, nos llegan ejemplos que estamos en el deber de imitar a lo menos en parte.

[...] Nuestros vecinos del Ecuador, por ejemplo, cuya cultura general no podría decirse que es superior a la nuestra, en 1918 abrogaron el régimen de la omnipotencia del marido sobre los bienes de la mujer, y adoptaron un principio que sería inconcebible que aún tuviera resistencia entre nosotros, a saber: el derecho de la mujer casada para usar o disponer libremente de los suyo cuando a bien lo tenga, o sea el reconocimiento del derecho de la mujer a que por el hecho del matrimonio no se la convierta en esclava.

Estos sencillos principios están incorporados desde hace varios años en casi todos los Códigos Civiles de los países europeos [...]

En Uruguay - pequeña nación que por muchos conceptos le hace honor a la América- desde 1907 consagró en su legislación el divorcio absoluto; en 1921 decretó la ciudadanía plena para la mujer [...] Y recientemente se ha propuesto a la consideración del Congreso uruguayo un Código completo sobre los derechos de la mujer [...]

Por lo que hace Chile, hasta acá nos llegaron, en 1919, los ecos de la recia campaña que por la emancipación de la mujer realizaba el Presidente Alessandri (ACR, sesiones ordinarias de 1931, serie 3a ${ }^{a}$ n. ${ }^{\circ} 53$ y 54, pp. 377 y 378).

\section{Contexto social: la organización de las mujeres}

Al inicio de la década de los treinta se vivía en el país un ambiente de expectativa frente a las reformas políticas, sociales y económicas que el nuevo gobierno liberal había prometido en campaña. Especialmente, las mujeres habían desempeñado un papel importante en el triunfo electoral del liberalismo, ya que a pesar de que no gozaban de derechos políticos, salieron a las plazas públicas a manifestar su apoyo al candidato Enrique Olaya Herrera (Velásquez Toro, 2004). Ganadas las elecciones presidencia- 
les, aquellas mujeres que tuvieron contacto político con el candidato Olaya Herrera, ahora presidente de la República, presionaban por la aprobación de las reformas normativas que se comenzaban a tramitar en el Congreso.

Ser escuchadas en un recinto puramente masculino, como lo era el Congreso de la República, no resultó fácil. Cada cámara era un grupo de hombres que, con la autoridad que ellos mismos se otorgaron, pasaban jornadas enteras hablando sobre las mujeres, sin la presencia de una sola de ellas. Con cada proyecto de ley en relación con las reivindicaciones femeninas disertaban sobre el supuesto de inferioridad de la mujer basado en la biología, sobre las diferencias entre lo masculino y lo femenino, sobre la idea de fragilidad y debilidad de la mujer impuesta por el cristianismo y las leyes románticas de la caballería, sin escuchar una sola voz femenina que con la autoridad que le da el hecho de ser mujer diera veracidad o acusara de falsas las afirmaciones que se decían sobre ellas.

No obstante lo anterior, un congresista reaccionó positivamente ante el gran esfuerzo de muchas mujeres por ser escuchadas. Al Senado de la República llegó, mediante telegrama, una solicitud de la señora Amalia López de Mesa, en que pedía al honorable Congreso que apoyara la reforma del Código Civil presentada por el Gobierno sobre capitulaciones matrimoniales. $^{5}$

Haciendo eco de la anterior solicitud mencionada, el senador Miguel Gómez Fernández, en la sesión del Senado del 18 de agosto de 1931, al finalizar una de sus intervenciones, recomendó la importancia del proyecto y su pronto estudio. Además, manifestó que "varias damas colombianas se habían dirigido a la Comisión de Legislación Civil para pedir la pronta aprobación de este proyecto" (ACR, sesiones ordinarias de 1931, serie $1^{\text {a }}$, n. ${ }^{\circ} 26$, p. 179). En respuesta a la solicitud de la señora de López de Mesa, la Comisión que tenía en estudio el proyecto sobre las capitulaciones matrimoniales se pronunció diciendo que "como el asunto es de alta trascendencia social" debía contestársele el telegrama en los siguientes términos:

5 En los Anales del Senado no se encuentra información de la fecha exacta en que el telegrama de la señora Amalia de López Mesa fue recibido por el Congreso. Sin embargo, teniendo en cuenta que fue contestado en agosto y que el proyecto de ley sobre capitulaciones matrimoniales estaba en el segundo debate para esa época, es muy probable que el mencionado telegrama se haya enviado entre julio y agosto de 1931. En tal caso, este telegrama sería parte de las múltiples solicitudes de mujeres que llegaron al Congreso pidiendo la aprobación de los proyectos de ley que afectaban sus derechos. 
Dígasele a la señora doña Amalia López de Mesa que el Senado prestará toda la atención que merece el proyecto de ley sobre capitulaciones matrimoniales, y que le complace ver la intervención que toma la mujer colombiana en asunto de tanta importancia (ACR, sesiones ordinarias de 1931, serie $1^{\text {a }}$, n. ${ }^{\circ} 26$, p. 179).

Paralelamente, pero por fuera del Congreso, otras mujeres se movían en otros espacios políticos con el fin de buscar unir todas las fuerzas que estaban a su alcance. Cuenta Magdala Velásquez Toro en la biografía que hizo de Ofelia Uribe de Acosta, que esta asistió a una reunión con el presidente Olaya con varias mujeres con las que tenía vínculos familiares, entre quienes se contaba ella, y "aquel les manifestó su satisfacción al ver a las mujeres por fin interesadas en sus derechos; estoy en total acuerdo con ustedes - les dijo- y este será uno de los primeros proyectos de mi gobierno" (Velásquez Toro, 2004, p. 12).

\subsection{Congreso Internacional Femenino}

De la mano del presidente Olaya, Ofelia Uribe de Acosta, en asocio con otras mujeres comprometidas con sus derechos, organizaron y lideraron el IV Congreso Internacional Femenino que tuvo lugar en Colombia en diciembre de 1930 (Velásquez Toro, 2004). Fue convocado por la Liga Internacional de Mujeres Ibéricas e Hispanoamericanas, a fin de conmemorar el centenario de la muerte del Libertador Simón Bolívar, pero auspiciado en una gran parte por la Nación. De ello da cuenta el "Proyecto de ley por el cual se asocia la Nación al cuarto Congreso Internacional Femenino", presentado el 29 de agosto de 1930 ante la Cámara, por el representante José M. Saavedra Galindo. Resulta ilustrador para percibir el clima político que se vivía en el interior del Congreso en 1930, la Exposición de Motivos con que se justificó tal proyecto:

El tercer Congreso Internacional Femenino se reunió en Buenos Aires en 1929. A este Congreso envió nuestra eminente compatriota señorita doña Georgina Fletcher, representante de la Liga en Colombia, y notable escritora y propulsora del feminismo, varios sobresalientes trabajos de mujeres colombianas sobre ciencias y artes, que fueron muy apreciados en aquel Congreso. La sociedad y las autoridades argentinas atendieron 
con el decoro debido a las delegaciones de todos los países, singularmente la de Colombia. Toca ahora a nuestra Patria corresponde con igual cortesanía y confraternidad internacionales, en esta ocasión propicia de la reunión de aquel Congreso en Bogotá. El solo hecho de que esta reunión se efectúe para honrar la luctuosa efemérides de la muerte del Padre de la Patria colombiana, sería motivo bastante para justificar el proyecto de ley os presento (ACR, sesiones ordinarias de 1930 , serie $1^{a}{ }^{2}$ n. ${ }^{\circ} 1$, p. 248).

Aunque la reivindicación de los derechos de las mujeres no fue el argumento principal, en dicha Exposición de Motivos se comenzó a crear un clima favorable para los derechos de las mujeres. Por medio de la idea de igualar la sociedad colombiana a la par de otras sociedades denominadas modernas por el gobierno de Enrique Olaya, el Congreso apoyó que un grupo de mujeres colombianas y de otras partes del mundo se reunieran para evaluar la situación de sus derechos. En palabras del representante Saavedra:

Colombia no puede quedarse atrás en este ritmo acelerado del progreso humano. En esta febril inquietud que mira como una meta llamativa la colocación de la mujer en el puesto que le corresponde en el reparto de los dones de Dios. Si solo esta conquista se lograra en definitiva en esta gran conmoción revolucionaria del mundo, eso bastará para justificarla y perdonar sus errores y demasías. Porque parece que esta gran inquietud espiritual busca como factor fundamental de sus realizaciones el triunfo del ideal de la mujer igual en deberes y en derechos, como garantía de la futura y definitiva victoria de la nueva organización humana.

Ya habéis visto cómo el señor Ministro de Gobierno, el ilustre expresidente doctor Carlos E. Restrepo, con mensaje especial, no acostumbrado sino en contados casos parlamentarios del actual Presidente Olaya Herrera, que así cumple uno de los números sobresalientes de su programa de gobierno, acaba de presentar, con aplauso general, un proyecto de reforma de nuestro Código Civil que consagra la igualdad patrimonial de la mujer casada. Sigamos ese ejemplo, démosle en nuestra esfera singular amplitud (ACR, sesiones ordinarias de 1930, serie $1^{\text {a }}$, n. ${ }^{\circ}$ 1, pp. 248 y 249).

El 16 de diciembre de 1930 se inauguraron en el Teatro Colón las sesiones del Congreso Femenino que duraron hasta el 23 del mismo mes, con la participación de las delegaciones de diez países extranjeros (España, México, 
Chile, Venezuela, Ecuador, Costa Rica, Cuba, Panamá, Perú y Estados Unidos) y de nueve delegaciones departamentales del país (Atlántico, Bolívar, Boyacá, Valle, Magdalena, Huila, Cauca, Santander del Norte y Santander del Sur). ${ }^{6} \mathrm{Al}$ acto inaugural asistió el ministro de Educación, quien dio inicio a las sesiones con un discurso en el que elogió la participación de la mujer en los actos del país. Señaló que:

No podría estar ausente la mujer de los actos con que el país y el mundo entero rinde tributo de admiración al Padre de la Patria, Simón Bolívar, fundador de cinco repúblicas, porque la mujer a través de la historia universal, y particularmente de nuestra historia, ha sido fiel a la memoria de los héroes que nos emanciparon y ha venido inspirando los actos que mueven el alma de la virtud, a la libertad y a la justicia, que porque tienen nombres femenino sólo las representa el bronce. [...] Me cabe el honor de declarar inaugurado, a nombre del señor presidente de la república, el cuarto congreso internacional femenino, y desearos un éxito completo en las labores que vais a iniciar (Exposición de cultura femenina, 1930).

La realización del Congreso Femenino realizado en Colombia despertó interés nacional y "produjo un alboroto morboso de sectores de la opinión pública, en un país en el cual las mujeres nunca se habían reunido para tratar asuntos que tenían que ver con su vida pública y privada" (Velásquez Toro, 2004). Pero, sobre todo, sirvió para concentrar en una sola agenda política las múltiples preocupaciones de las feministas colombianas de la época, en una lucha propia del feminismo liberal. El diario El Tiempo transcribió la totalidad del programa de actividades que se llevarían a cabo durante los días en que duraría el Congreso. En este figuran muchas actividades relacionadas con la conmemoración del primer centenario de la muerte de Simón Bolívar. Por ejemplo, para el día 16 de noviembre, a las 10 y 30 de la mañana:

[...] las socias del Centro femenil colombiano recibirán a las delegadas en la Quinta de Bolívar, donde se les ofrecerá una copa de champaña. Luégo [sic] la presidenta del Centro saludará a las delegadas. Tanto las socias del Centro como las delegadas escribirán un pensamiento en

6 Para información más detallada véase anexo 2 . 
honor del Libertador, en un álbum que el Centro tiene para ese objeto. [...] El día 17 en las horas de la mañana, el congreso asistirá a las honras fúnebres en la Basílica Primada. A las 3 p. m.: El congreso desfilará desde el Parque de Santander por la carrera 7a., llegará hasta la plaza de Bolívar y al pie de la estatua del Libertador, hablará la vicepresidenta del Centro; se depositará allí la ofrenda floral. [...] El día 18 a las 3 p. m. el Congreso visitará el Museo Nacional, y allí su director, el doctor Gerardo Arrubla, dictará una conferencia sobre prehistoria (Esta noche inaugura sus sesiones el IV Congreso Internacional de Mujeres, 1930).

Aunque sí había un interés dirigido a rendir homenaje al Libertador, tal y como da cuenta el programa de actividades publicado en el diario El Tiempo, las mujeres que se dieron cita en el Congreso presentaron "un número importante de ponencias que trataban temas relativos a la efemérides que las reunía, y otras sobre diversos asuntos relativos a la condición de las mujeres en esa época" (Velásquez Toro, 2004). Entre ellas se encontraba la ponencia de la señorita Claudia Múnera sobre su trabajo de la "Mujer y el hogar", que según la opinión pública resultó "novedoso en sus conclusiones y avanzado en sus ideas". La de la señorita Beatriz Arias de Cajiao, de la delegación de Panamá, que mereció especial mención y trató sobre los derechos generales de la mujer, y la de la señorita Georgina Fletcher, sobre la mujer colombiana que había sido leída en Lima durante la 2. Conferencia Panamericana de Mujeres (Esta noche inaugura sus sesiones el IV Congreso Internacional de Mujeres, 1930).

Entre las ponencias que se presentaron en el Congreso Femenino, se destacó la de Ofelia Uribe de Acosta, ${ }^{7}$ delegada del gobernador de Boyacá, Celso Rodríguez. Presentó un trabajo sobre los derechos civiles de la mujer casada titulado "Contribución al estudio de la reforma Olaya-Restrepo sobre el régimen de las capitulaciones matrimoniales" que fue publicado en su totalidad por el diario El Tiempo (El Proyecto de capitulaciones matrimoniales en el congreso femenino, 1931). En este indicaba su interés y

7 Ofelia Uribe de Acosta fue luchadora y dirigente santandereana del feminismo sufragista (Ibagué, diciembre 22 de 1900-Bogotá, agosto 4 de 1988), que se manifestó en Colombia desde los inicios de la segunda República Liberal (1930) hasta principios del Frente Nacional. Fue exponente de una generación de mujeres que irrumpieron en la vida nacional para luchar por el respeto a su dignidad humana y por el reconocimiento de los derechos civiles y políticos de las mujeres colombianas (Velásquez Toro, 2004). 
profundo esfuerzo por que se reformara el Código Civil en lo relacionado con las capitulaciones matrimoniales en tanto que solicitó se nombrara

[...] por la presidencia una comisión de delegadas [del] cuarto congreso internacional femenino, para que concurra a la honorable cámara de representantes y al senado de la republica [sic], a sostener la urgente necesidad y conveniencia de que el proyecto de reforma al código civil sobre capitulaciones matrimoniales, presentado por el ejecutivo, sea ley de la república (El debate sobre capitulaciones matrimoniales, 1930).

Así mismo, se refería a la trascendencia que tenía para las mujeres la que fue la primera propuesta legislativa presentada por el gobierno, con la que se abrió el debate sobre los derechos económicos de las mujeres casadas. Además, sustentó la necesidad de que tuvieran independencia económica y pudieran manejar sus propios bienes, y las convocaba a presionar a las cámaras legislativas para lograr su aprobación. Narra Magdala Velásquez Toro que en una entrevista hecha a Ofelia Uribe de Acosta esta recordaba que el día de su conferencia en el Teatro Colón: "se llenaron las instalaciones, asistió el parlamento, [y] una multitud que se había quedado sin poder entrar por falta de cupo, rompió las puertas del teatro e invadió el recinto". Luego afirmó que:

Ante ese público, el feminismo acaba de nacer en Colombia como producto natural de evolución, pero todavía son muchas las mujeres que retroceden espantadas ante la repentina aparición de esa palabra que viene a turbar su mísera condición de siervas humilladas, pero insensiblemente connaturalizadas con su papel de víctimas (Velásquez Toro, 2004).

\subsection{El activismo de las mujeres llega hasta el Congreso de la República}

Tanto la ponencia de Ofelia Uribe como la de Gloria Rodríguez tuvieron gran trascendencia a la hora de presionar para la aprobación de los proyecto de ley que trataban sobre los derechos de la mujer. En Tunja, Ofelia Uribe convocó a quinientas mujeres que firmaron una carta en la que pedían acabar con la discriminación sexual que equiparaba a las mujeres a los 
incapaces absolutos (Velásquez Toro, 2004). En la entrevista que Magdala Velásquez le hizo a Ofelia Uribe, cuenta esta última que:

En el proceso de aprobación de la que llegó a ser la ley 28 de 1932, mediante la cual se otorgó a las casadas la capacidad y el derecho para manejar sus propios bienes dentro del matrimonio, participaron las mujeres. Como grupo de presión, se hacían presentes en las sesiones del Congreso, lideradas por Clotilde García de Ucrós; en esa época Ofelia Uribe vivía en Santander, pero viajaba con frecuencia a la capital para participar en las deliberaciones (Velásquez Toro, 2004).

El periódico El Tiempo tenía una sección que informaba sobre los proyectos de ley que se llevaban en el Congreso. En pocas oportunidades registraba la totalidad de los debates sobre un solo tema. Sin embargo, en esta oportunidad registró totalmente los debates del día en que hubo presencia femenina. La noticia se publicó así:

LA CÁMARA DEDICÓ AL RÉGIMEN PATRIMONIAL SU SESIÓN AYER. [...] Régimen patrimonial. A continuación se prosiguió el segundo debate del proyecto de ley sobre régimen patrimonial o libre administración de los bienes propios por la mujer casada. Para este debate había un numeroso y selecto público femenino y feminista (La Cámara dedicó al régimen patrimonial su sesión ayer, 1932).

La presión del auditorio femenino fue sentida por el orador que inició el debate, ya que inició su discurso declarando "que no quería en manera alguna dejar que prosperara la creencia de que es opuesto a que se legisle en materia de tánta [sic] importancia y que ciertamente necesita una radical transformación en el régimen jurídico civil" (La Cámara dedicó al régimen patrimonial su sesión ayer, 1932). Ocurría que el orador era el representante Joaquín Emilio Sierra, miembro de la Comisión, que tenía a cargo estudiar la viabilidad del proyecto de ley sobre reformas al régimen matrimonial o sociedad conyugal, quien había presentado el Informe de Minoría adverso a que el proyecto se convirtiera en ley. Sin embargo, a pesar de su profundo convencimiento de que tal proyecto no debía prosperar, inició su discurso enfatizando que no estaba en contra del proyecto, sino que su inconformidad era de tipo jurídico, porque: 
[...] el artículo primero de este [el proyecto] es contradictorio en su misma redacción. Principia por reconocer la existencia de la sociedad conyugal que se entiende como una refundición de bienes manejados por una persona responsable, y a renglón seguido se afirma perentoriamente que cada uno de los cónyuges tiene la libre disposición de los bienes aportados al matrimonio. Hubiera sido preferible, puesto que se trata de una reforma radical, suprimir esa primera parte y dejar escueta la segunda afirmación (ACR, sesiones extraordinarias de 1932, serie $2^{a},{ }^{\mathrm{a}}{ }^{\circ}{ }^{57}$, p. 316).

Pero lo cierto era lo que había escrito en dicho Informe de Minoría en el que ciertamente criticaba el artículo primero del proyecto de ley, pero también construía la idea de que tal proyecto era un peligro para el orden social y familiar por contener una figura jurídica importada del exterior. Argüía que:

Para legislar sobre esta materia debemos tener presente que vivimos en Colombia, donde las costumbres y la civilización de la mujer no han alcanzado los límites de la cultura y civilización europeas. Del mismo modo, es preciso despojarnos de la idea común de creer que las costumbres y el ambiente de algunos centros sociales es el imperante en el país; como es también un error legislar tomando como norma [sic] casos de excepción. [...] Para legislar con criterio práctico debemos servirnos en el criterio nacional, preparándolo si es que aún no lo tenemos, pero en ningún caso transfundiendo principios y teorías que por lo desadaptados pueden llevarlos al desquiciamiento de la familia y del propio Estado culto y cristiano que la moral y la virtud de nuestra mujer ha cultivado, amparada por la fuerza racial. Abrigo fundados temores de que las disposiciones que comtempla [sic] el proyecto tiendan al implantamiento de regímenes que rechazan la educación y la ideología esencialmente cristiana del pueblo colombiano, la moral y las costumbres familiares y hogareñas de nuestra raza (ACR, sesiones extraordinarias de 1932 , serie $2^{a}$, n. ${ }^{\circ} 57$, p. 316).

Georgina Fletcher también participó del activismo de concientización de otras mujeres sobre sus derechos. Como estrategia de presión en el Congreso, recogió 59 firmas que respaldaban un memorial dirigido al presidente y demás miembros de la Cámara de Representantes. En la sesión del 1. ${ }^{\circ}$ de octubre el memorial fue leído por Georgina en los siguientes términos: 
En nombre de la mujer colombiana y en el nuestro, con el debido respeto, solicitamos de esa honorable corporación, que dignamente integráis, se continúe el estudio de los muy justos proyectos sobre régimen patrimonial y otros, que en buena y oportuna hora prestó el Excelentísimo señor Presidente de la República a la consideración del Congreso Nacional. [...] Reconociendo la positiva diligencia y laboriosidad de la mujer en favor de la familia, demostrando la efectividad de la sociedad conyugal, habéis enaltecido el hogar y afianzado definitivamente el sagrado vínculo del matrimonio probando hasta la saciedad en el terreno jurídico que el proyecto no trastorna el orden civil, ni el legislativo. Alguno de vosotros con verdadera elocuencia, [...] habéis considerado nuestra situación de manera tan clara y tan precisa que la honorable Cámara ha quedado suficientemente ilustrada y convencida, demostrando solidario interés para que pase el proyecto que nos favorece o mejor dicho, nos hace justicia (ACR, sesiones ordinarias de 1932 , serie $2^{\text {a }}$, n. $^{\circ} 79$, p. 465).

\section{Debate jurídico de la Ley 28 de 1932}

Aunque resultaba cierta la complejidad jurídica que contenía el proyecto de ley sobre reformas civiles - régimen patrimonial en el matrimonio-, los debates alrededor mostraban que fueron más una excusa para oponerse al interés ideológico del proyecto que una verdadera razón jurídica de fondo. El proyecto tenía tanto el propósito político de hacer un adelanto institucional en gran escala que nos igualara a otros países que reconocían jurídicamente la igualdad de géneros como un interés por reconocer las capacidades de las mujeres casadas.

En este ambiente se enfrentaron en una misma sesión, la del 2 de septiembre de 1932, en la Cámara de Representantes, dos bandos. Por un lado, contra el proyecto, el representante Joaquín Emilio Sierra anotaba que este no solucionaba el mal que aquejaba a la mujer casada, el que desde su posición era el abuso de algunos maridos que veían en el matrimonio con una mujer acaudalada un negocio para resolver su situación económica y no la inferioridad y subordinación en que la ley ponía a la mujer con respecto a su marido. En su intervención frente al Congreso de la República así lo manifestó: "porque el mal que debemos corregir es el abuso de los maridos y no la exageración de una libertad que seguramente nuestra mujer 
no está educada ni capacitada para ejercer con la prudencia que la vida de los negocios reclama" (ACR, sesiones extraordinarias de 1932, serie $2^{\text {a }}$, n. ${ }^{0}$ 51, p. 287). Seguidamente expuso su crítica al proyecto así:

No entraré a estudiar y analizar los puntos que trato en mi informe, porque me haría interminable, sobre cuestiones que han sido largamente debatidas en el Parlamento y en la Cámara. Solo quiero manifestar, y deseo que de ello quede expresa constancia, que al rendir informe por separado lo hice porque el de mis compañeros analiza y acoge principios contrarios a las ideas y enseñanzas que profeso [...]

$[\ldots]$

Con respecto al artículo $1^{\circ}$, anoto que en él se contempla a la vez la existencia e inexistencia de la sociedad conyugal, desde luego que dice que por el hecho del matrimonio se contrae sociedad conyugal, y a renglón seguido otorga a los cónyuges la libre disposición y administración de los bienes de cada uno de ellos. Yo no concibo la existencia de una sociedad conyugal sin patrimonio común. [...] Se me hace exótico y un poco desadaptado a la ciencia jurídica hablar de sociedad conyugal en teoría durante la vida de los cónyuges, y luego de disolución y liquidación de una cosa que en vida no ha existido.

[...]

Por el artículo $2^{\circ}$ se atiende a la constitución activa del patrimonio de los cónyuges y nada se dice en cuanto a las cargas comunes que los bienes de éstos deben soportar. Considero que debe aclararse esta disposición porque, $[\ldots .$.$] se debe indicar y se debe indicar cómo cada uno de los$ cónyuges y en qué proporción atienden a la obligación de la educación y crianza de la prole, a la vez que de los mismos cónyuges [...]

$\mathrm{El}$ artículo $3^{\circ}$ establece que no vale entre cónyuges ningún contrato referente a inmuebles, salvo el de mandato general o especial. Tal como está esta disposición en realidad de verdad no ha de salvaguardar los intereses de la mujer casada, porque de una parte solo se refiere a los contratos referentes a inmuebles, y hay contratos que sin referirse a inmuebles son más peligrosos para los intereses de la mujer y la expone a mayores abusos, como el de fianza a favor del marido, el cual no queda comprendido en la disposición $[. .$.

[...]

Respecto al artículo $5^{\circ}$ debo decir que él no prevé el caso de la representación de la mujer menor de edad. ¿A ella quién la representa, honorable Representante? ¿Tendrá que nombrársele curador, o lo será su 
padre, un pariente o el marido mismo? (ACR, sesiones extraordinarias de 1932, serie $2^{\mathrm{a}}$, n. ${ }^{\circ}$ 51, p. 286).

Por el otro lado, defendiendo el proyecto, se encontraban los representantes Lozano y Lozano, Jorge Eliécer Gaitán, Esguerra Serrano y el abogado consultor de la Presidencia de la República, Luis Felipe Latorre. El primero replicó concisamente que "no se trata únicamente de que queden asegurados los haberes de la mujer, sino de que ella tenga una libertad absoluta que la coloque en iguales condiciones de la mujer soltera y del marido mismo" (ACR, sesiones extraordinarias de 1932, serie $2^{\text {a }}$, n. ${ }^{\circ}$ 51, p. 288). Además, se dio a la tarea de replicar las críticas jurídicas que el representante Sierra había formulado en su intervención, como explicar que en lo referente al artículo $5^{\circ}$ del proyecto "en verdad se hace ese vacío [sobre la representación de la mujer menor de edadl, honorable Representante, y esa misma observación le hice al doctor Latorre, autor del proyecto. Y él me dijo que podría modificarse o aclararse nombrando al marido, lo mismo que para la mujer demente" (ACR, sesiones extraordinarias de 1932, serie $2^{\text {a }}$, n. $^{\circ} 51$, p. 288). El representante Jorge Eliécer Gaitán intervino solamente para discutir el criterio del representante Sierra sobre la incapacidad de la mujer colombiana para la vida de los negocios, al cuestionar que "si seguimos legislando con ese criterio, entonces ¿cuándo es que vamos a darle ocasión a la mujer para que adquiera disciplina?" (ACR, sesiones extraordinarias de 1932 , serie $2^{\text {a }}$, n. ${ }^{\circ}$ 51, p. 288). Por su parte, el abogado consultor de la Presidencia de la República, Luis Felipe Latorre, en defensa de las críticas del representante Sierra hacia el proyecto presentado, explicó el objetivo de cada artículo en los siguientes términos:

Como ya se dijo, los artículos $1^{\circ}, 2 .^{\circ}$ y $5 .^{\circ}$ del proyecto de ley, establecen la independencia patrimonial y la libertad jurídica de los cónyuges.

El artículo 3. ${ }^{\circ}$ evita tanto las maniobras indebidas de contratos simulados entre marido y mujer, para burlar a los acreedores, como el plagio de que maridos codiciosos y sin escrúpulos llegan a quedarse con el patrimonio de sus mujeres demasiado complacientes, dóciles o pusilánimes.

El artículo $6 .^{\circ}$, en estricto rigor innecesario, porque aun suprimiéndolo debe entenderse que el régimen patrimonial proyectado no tiene porqué descargar a los cónyuges de sus obligaciones familiares, [...] se justifica parrla desvanecer completamente cierto temor infundado, pero que se 
hizo ostensible, de que la nueva ley viniera a librar al marido de sus deberes para con la mujer y los hijos, cosa en que no se ha pensado.

En esta libertad o independencia (consagradas en los artículos $1 .^{\circ} \mathrm{y}$ $2^{\circ}$ del proyecto) se traduce la justa aspiración de la mujer, sin que los terceros tengan motivo de queja, porque una vez expedida la ley quedan enterados de que sus relaciones con personas casadas deben obrar como si negociaran con personas solteras, sencillamente; y la suma de gananciales al disolverse la sociedad, para ser partidos por iguales partes (artículo 4 . $^{\circ}$ ), responde a la equidad en defensa de la mujer, y salvar el inconveniente de las separaciones ordenadas de bienes (que por otra parte no se realizan fácilmente en la práctica aunque se den todos los medios imaginables, hasta el de la simple voluntad de la mujer) (ACR, sesiones extraordinarias de 1932 , serie $2^{\text {a }}$, n. $^{\circ}$ 51, p. 288).

Finalmente, el representante Esguerra Serrano respondió a algunas afirmaciones hechas por el representante Sierra en el Informe de Minoría que presentó a título propio, en los siguientes términos:

El verdadero argumento, repito, del Representante Sierra contra el proyecto está en su informe, en donde afirma también que el proyecto tiene al implantamiento de regímenes que rechazan la educación y la ideología esencialmente cristianas del pueblo colombiano. No, honorable representante, no hable Su Señoría de cristianismo para atacar este proyecto de liberación de la mujer. No olvide Su Señoría que fue el cristianismo quien vino a emancipar y a dignificar a la mujer (ACR, sesiones extraordinarias de 1932 , serie $2^{\text {a }}$, n. ${ }^{\circ}$ 51, p. 289).

En anteriores sesiones, el gobierno del presidente Enrique Olaya Herrera había manifestado el total apoyo a este proyecto de ley a través de los ministros Agustín Morales, de Gobierno; Esteban Jaramillo, de Hacienda, y Francisco José Chaux, de Industria, quienes manifestaron que:

[...] el Gobierno quiere reiteraros su decidido empeño por la reforma que reconozca y garantice a la mujer casada una más extensa capacidad civil, tanto en busca del merecido enaltecimiento de su personería, como en guarda de su patrimonio, especialmente del que proceda de su propio esfuerzo. 
No parece justo que al tiempo que las sociedades que no han alcanzado nuestra cultura en estas materias, han realizado en mayor o menor escala tal adelanto en sus instituciones a un movimiento respaldado por la equidad y por las nociones más sanas de auténticas civilización.

Solamente el espíritu irreductiblemente egoísta de parte del hombre, o la idea errónea de que las capacidades intelectuales de la mujer colombiana son inferiores a las demás, justificaría el estado de pupilaje en que se la mantiene (ACR, sesiones extraordinarias de 1932 , serie $1^{\text {a }}$, n. $^{\circ} 17$, p. 87 ).

Una vez los debates correspondientes, el proyecto fue sometido a la Comisión de Legislación Civil, que le introdujo las modificaciones debatidas y aprobadas en la sesión del 5 de octubre de 1932 (ACR, sesiones ordinarias de 1932, serie $2^{a}$, n. $^{\circ} 87$, p. 530). Tales proposiciones finales de la Comisión de Legislación Civil fueron aprobadas y enviadas al Senado de la República. En el Senado, en la sesión del 11 de octubre de 1932, se consideró en primer debate el proyecto remitido por la Cámara y fue aprobado (ACR, sesiones ordinarias de 1932, serie $2^{\text {a }}$, n. ${ }^{\circ}$ 91, p. 532). Pasó en comisión, con seis días de término, a la de Legislación Civil (ACR, sesiones ordinarias de 1932, serie $2^{\text {a }}$, n. ${ }^{\circ}$ 91, p. 532). En la sesión del 22 de octubre se leyó el informe final en los siguientes términos:

En relación con el proyecto "sobre reformas civiles (régimen patrimonial en el matrimonio)", tenemos el honor de informaros:

Dicho proyecto es una reforma radical al sistema actual de nuestro Código Civil, ya que coloca a la mujer casada en la misma condición jurídica del marido, en lo que respecta a la facultad de disponer y administrar sus propios bienes, comparecer en juicio. Contratar, etc.; pone fin a la sociedad o comunidad de bienes durante el matrimonio, y liberta a la mujer de la tutela oficiosa del Juez, tutela basada en un criterio proteccionista y paternal.

El salto es prodigioso: de la incapacidad casi absoluta, a la absoluta capacidad civil: la mujer no solo tiene la libre disposición sobre sus bienes, libertad no limitada por ninguna traba judicial, sino que los administra con independencia completa del marido. Existe en el hecho y en derecho total separación de patrimonios.

[c]Es justa esta reforma? Ninguno lo discute (ACR, sesiones ordinarias de 1932 , serie $2^{\text {a }}$, n. $^{\circ} 100$, pp. 565 y 566 ). 


\section{Conclusiones}

La situación jurídica en la que se encontraba la mujer casada colombiana antes de 1932 era de completa incapacidad civil, lo que la ponía en idéntico nivel jurídico que un retrasado mental o un menor de edad, y ello le generaba un estado de desigualdad y opresión frente a su esposo. Fue en el gobierno del presidente Enrique Olaya Herrera en el que el asunto cobró importancia al punto que, tomando la iniciativa, presentó ante el Congreso varios proyectos de ley tendientes a reformar tan injusta situación jurídica. Luego de varios debates en la Cámara de Representantes y el Senado, se promulgó la Ley 28 de 1932, que reformó el régimen patrimonial del matrimonio y le dio a la mujer casada la completa capacidad civil.

Mediante la revisión y análisis de los debates en el Congreso del proyecto de ley denominado "sobre reformas civiles-régimen patrimonial en el matrimonio", presentado en 1931, que duraron hasta 1932, y de las noticias que registraron los diarios El Tiempo y El Espectador sobre la movilización de algunas mujeres a favor del proyecto, se estableció, primero, que el gobierno de Enrique Olaya Herrera se enfrentó a un Congreso que se oponía fuertemente a la reforma de las normas que regulaban los derechos civiles y económicos de las mujeres. Tuvo que resistir al archivo de varios proyectos presentados en la Cámara de Representantes y en el Senado. Así mismo, tuvo que insistir numerosas veces para que se realizaran los debates a que había lugar, pues se suspendían o se negaban o se aplazaban. Una vez en los debates, varios ministros, abogados, el propio presidente y algunos congresistas se dieron a la ardua tarea de defender una y otra vez el articulado del proyecto con argumentos no solo jurídicos, sino de género. Esta insistencia y compromiso mostrado por el presidente Olaya Herrera y su gobierno en la reforma que dio lugar la Ley 28 de 1932 determinaron que la posición política frente a la reivindicación de los derechos de las mujeres, en especial los derechos civiles y económicos de la mujer casada, era favorable y acorde con las promesas hechas en su campaña como candidato a la Presidencia.

Segundo, se estableció también que el recorrido de la Ley 28 de 1932 estuvo acompañado de la participación femenina y que esta fue importante y de gran ayuda para la aprobación del proyecto "sobre reformas civiles-régimen patrimonial en el matrimonio". Las mujeres activistas 
que propugnaban por sus derechos se organizaron y realizaron en Bogotá, en diciembre de 1930, el IV Congreso Internacional Femenino, nutrido de numerosas ponencias que reflexionaban sobre la mujer y su situación de esclavitud dentro del matrimonio. Algunas de las ponencias, como la de Ofelia Uribe de Acosta, fueron presenciadas por periodistas que registraban los discursos en los diarios de mayor circulación nacional de la época y dieron a conocer a la sociedad las ideas y posiciones femeninas. Además, hubo varios telegramas y cartas enviadas por distinguidas damas al Congreso de la República, con la solicitud de aprobación de los diferentes proyectos presentados por el gobierno que pretendían mejorar la situación jurídica de la mujer. Finalmente, Georgina Fletcher llegó al Congreso y, de viva voz, leyó frente a los representantes de la Cámara un memorial dirigido al presidente Olaya Herrera y a ellos mismos, en el que solicitaba el estudio y aprobación del proyecto sobre la reforma al régimen patrimonial y agradecía a quienes defendían su causa.

Por último, se estableció que los esfuerzos dirigidos a la aprobación de la Ley 28 de 1932 eran parte de un proyecto más grande y ambicioso de la República Liberal, liderado por el presidente Olaya Herrera, al que se refería como "de modernización de la sociedad colombiana". En varios discursos presentados frente al Congreso en defensa del proyecto sobre reformas civiles-régimen patrimonial del matrimonio" se mencionó tal interés. Por lo tanto, se entiende que la idea de modernización de la sociedad colombiana iba ligada con las reformas de algunas leyes en igual sentido que otras sociedades reconocidas como más civilizadas y progresistas lo habían hecho. Por ejemplo, varios miembros del gobierno del presidente Olaya Herrera argumentaban que países como Suecia, Finlandia, Noruega y Dinamarca eran parte de un movimiento universal que perseguía la emancipación económica de la mujer y, por ello, eran sociedades más avanzadas que la colombiana. En ese sentido, existió un proyecto de "modernización" del que la Ley 28 de 1932 hizo parte.

\section{Referencias}

Anales de la Cámara de Representantes, Sesiones Ordinarias de 1930: serie 1ª́ (número 1); de 1931: serie $1^{\text {a }}$ (números $11,21,26$ ), serie $2^{\text {a }}$ (números 91 y 100), 
serie $3^{a}$ (números 53, 54 y 116); de 1932: serie $1^{\text {a }}$ (número 18), serie $2^{a}$ (números 79, 87, 91 y 100). Imprenta Nacional, Bogotá. Imprenta Nacional, Bogotá. Anales de la Cámara de Representantes, Sesiones Extraordinarias de 1932: serie $1^{\text {a }}$ (números 17, 18, 51 y 57). Imprenta Nacional, Bogotá.

Código Civil colombiano. (1887). Bogotá: Temis.

Deere, C. D. (2005). Married Women's property rights as human rights: The Latin American contribution. Florida Journal of International Law, 101-113.

El Congreso Femenino. (15 de diciembre de 1930). El Tiempo (6899), 55.

El debate sobre capitulaciones matrimoniales. (20 de diciembre de 1930). El Tiempo (6904), 1.

El Proyecto de capitulaciones matrimoniales en el congreso femenino. (1 de enero de 1931). El Tiempo (6915), 23 y 25.

Esta noche inaugura sus sesiones el iv Congreso Internacional de Mujeres. (16 de diciembre de 1930). El Tiempo (6900), 25.

Exposición de cultura femenina. (17 de diciembre de 1930). El Tiempo (69001), 7. Glendon, M. A. (1974). Matrimonial property: A comparative study of law and social change. Tulane Law Review, 21-83.

Jaramillo, I. C. (2013). Derecho y familia en Colombia: historias de raza, género y propiedad (1540-1980).Bogotá: Ediciones Uniandes.

La Cámara dedicó al régimen patrimonial su sesión ayer. (3 de septiembre de 1932). El Tiempo (7515), 9.

Lafont Pianetta, P. (2013). Derecho de familia, derecho marital, filiación funcional, derechos sexuales y reproductivos (tomo II). Bogotá: Librería Ediciones del Profesional. Lavrin, A. (2005). Mujeres, feminismo y cambio social en Argentina, Chile y Uruguay 1890-1940. Santiago de Chile: Dirección de Bibliotecas, Archivos y Museos. León, M. y Eugenia, R. (2005). ¿Ruptura de la inequidad?: propiedad y género en la América Latina del siglo XIX. Bogotá: Siglo del Hombre.

Mañana se reune el IV Congreso de Mujeres a las 9. (15 de diciembre de 1930). El Espectador (6745), 1 у 2.

Monroy Cabra, M. G. (2007). Derecho de familia y de menores (10 $\mathrm{a}$ ed. corregida, aumentada y actualizada). Bogotá: Librería Ediciones del Profesional.

Parra Benítez, J. (2008). Derecho de familia. Bogotá: Temis.

Suárez Franco, R. (2006). Derecho de familia (tomo I). Bogotá: Temis.

Torres, J. O. (1970). Código Civil colombiano con notas, concordancias, jurisprudencia de la Corte Suprema de Justicia y normas legales complementarias. Bogotá: Temis. Valencia Zea, A. (1970). Derecho civil (Tomo V. Derecho de Familia). Bogotá: Temis. Velásquez Toro, M. (2004). Ofelia Uribe de Acosta. Bogotá: Biblioteca Virtual del Banco de la República. 
Anexo 1. Comparativo de la normatividad anterior y la Ley 28 de 1932

\begin{tabular}{|c|c|}
\hline Ley 57 de 1887: Código Civil & Ley 28 de 1932 \\
\hline $\begin{array}{l}\text { Art. 177. La potestad marital es el conjunto } \\
\text { de derechos que las leyes conceden al marido } \\
\text { sobre la persona y bienes de la mujer. }\end{array}$ & $\begin{array}{l}\text { Art. 1. Durante el matrimonio cada uno de los } \\
\text { cónyuges tiene la libre administración y dispo- } \\
\text { sición tanto de los bienes que le pertenezcan } \\
\text { al momento de contraerse el matrimonio o } \\
\text { que hubiera aportado a él, como de los demás } \\
\text { que por cualquier causa hubiere adquirido o } \\
\text { adquiera. }\end{array}$ \\
\hline $\begin{array}{l}\text { Art. } 180 \text {. Por el hecho del matrimonio se } \\
\text { contrae sociedad de bienes entre los cónyuges, } \\
\text { y toma el marido la administración de los de la } \\
\text { mujer }[\ldots . . .]\end{array}$ & $\begin{array}{l}\text { Art. 1. Durante el matrimonio cada uno de los } \\
\text { cónyuges tiene la libre administración y disposi- } \\
\text { ción tanto de los bienes que le pertenezcan al } \\
\text { momento de contraerse el matrimonio o que } \\
\text { hubiera aportado a él, como de los demás que } \\
\text { por cualquier causa hubiere adquirido o ad- } \\
\text { quiera }[. . .]\end{array}$ \\
\hline $\begin{array}{l}\text { Art. 181. Sin autorización escrita del marido no } \\
\text { puede la mujer casada parecer en juicio, por sí, ni } \\
\text { por procurador, sea demandado, o defendién- } \\
\text { dose. [...] }\end{array}$ & $\begin{array}{l}\text { Art. 5. La mujer casada, mayor de edad, como } \\
\text { tal, puede comparecer libremente en juicio, y para } \\
\text { la administración y disposición de sus bienes } \\
\text { no necesita autorización marital ni licencia del } \\
\text { juez, ni tampoco el marido será su representante. }\end{array}$ \\
\hline $\begin{array}{l}\text { Art. 182. La mujer no puede sin autorización del } \\
\text { marido, celebrar contrato alguno, ni desistir de } \\
\text { un contrato anterior, ni remitir una deuda, ni } \\
\text { aceptar o repudiar una donación, herencia o } \\
\text { legado, ni adquirir a título alguno oneroso o } \\
\text { lucrativo, ni enajenar, hipotecar o empenar. }\end{array}$ & $\begin{array}{l}\text { Art. 5. La mujer casada, mayor de edad, como } \\
\text { tal, puede comparecer libremente en juicio, } \\
\text { y para la administración y disposición de sus } \\
\text { bienes no necesita autorización marital ni licencia } \\
\text { del juez, ni tampoco el marido será su repre- } \\
\text { sentante. }\end{array}$ \\
\hline $\begin{array}{l}\text { Art. 183. La autorización del marido deberá ser } \\
\text { otorgada por escrito o interviniendo él mismo, } \\
\text { expresa y directamente, en el acto. No podrá } \\
\text { presumirse la autorización del marido sino en } \\
\text { los casos que la ley ha previsto. }\end{array}$ & $\begin{array}{l}\text { Art. 5. La mujer casada, mayor de edad, como } \\
\text { tal, puede comparecer libremente en juicio, y } \\
\text { para la administración y disposición de sus bie- } \\
\text { nes no necesita autorización marital ni licencia del } \\
\text { juez, ni tampoco el marido será su representante. }\end{array}$ \\
\hline $\begin{array}{l}\text { Art. } 186 . \text { El marido podrá revocar a su arbi- } \\
\text { trio, sin efecto retroactivo, la autorización general } \\
\text { o especial que haya concedido a la mujer. }\end{array}$ & $\begin{array}{l}\text { Art. 5. La mujer casada, mayor de edad, como } \\
\text { tal, puede comparecer libremente en juicio, y } \\
\text { para la administración y disposición de sus bie- } \\
\text { nes no necesita autorización marital ni licencia del } \\
\text { juez, ni tampoco el marido será su representante. }\end{array}$ \\
\hline $\begin{array}{l}\text { Art. 187. El marido puede ratificar los actos pa- } \\
\text { ra los cuales no haya autorizado a su mujer, y la } \\
\text { ratificación podrá ser también general o espe- } \\
\text { cial. La ratificación podrá ser tácita, por hechos } \\
\text { del marido que manifiesten inequívocamente } \\
\text { su aquiescencia. }\end{array}$ & $\begin{array}{l}\text { Art. 5. La mujer casada, mayor de edad, como } \\
\text { tal, puede comparecer libremente en juicio, } \\
\text { y para la administración y disposición de sus } \\
\text { bienes no necesita autorización marital ni licencia } \\
\text { del juez, ni tampoco el marido será su repre- } \\
\text { sentante. }\end{array}$ \\
\hline
\end{tabular}

Continúa 


\begin{tabular}{|c|c|}
\hline Ley 57 de 1887: Código Civil & Ley 28 de 1932 \\
\hline $\begin{array}{l}\text { Art. 188. La autorización del marido podrá ser } \\
\text { suplida por la del juez con conocimiento de causa, } \\
\text { cuando el marido se la negare sin justo moti- } \\
\text { vo y de ello se siga perjuicio a la mujer. Podrá } \\
\text { asimismo ser suplida por el juez en caso de } \\
\text { algún impedimento del marido, como el de } \\
\text { ausencia real o aparente, cuando de la demora } \\
\text { se siguiere perjuicio. }\end{array}$ & $\begin{array}{l}\text { Art. 5. La mujer casada, mayor de edad, como } \\
\text { tal, puede comparecer libremente en juicio, } \\
\text { y para la administración y disposición de sus } \\
\text { bienes no necesita autorización marital ni licencia } \\
\text { del juez, ni tampoco el marido será su repre- } \\
\text { sentante. }\end{array}$ \\
\hline $\begin{array}{l}\text { Art. 189. Ni la mujer ni el marido, ni ambos } \\
\text { juntos, podrán enajenar o hipotecar los bienes raíces } \\
\text { de la mujer, sino en los casos y con las formali- } \\
\text { dades que se dirán en el título De la Sociedad } \\
\text { Conyugal. }\end{array}$ & $\begin{array}{l}\text { Art. 5. La mujer casada, mayor de edad, como } \\
\text { tal, puede comparecer libremente en juicio, y } \\
\text { para la administración y disposición de sus bienes } \\
\text { no necesita autorización marital ni licencia del juez, } \\
\text { ni tampoco el marido será su representante. }\end{array}$ \\
\hline $\begin{array}{l}\text { Art. 191. La autorización judicial representa la } \\
\text { del marido, y produce los mismos efectos, con } \\
\text { la diferencia que va a expresarse. [...] }\end{array}$ & $\begin{array}{l}\text { Art. } 5 \text {. La mujer casada, mayor de edad, como } \\
\text { tal, puede comparecer libremente en juicio, } \\
\text { y para la administración y disposición de sus } \\
\text { bienes no necesita autorización marital ni licencia } \\
\text { del juez, ni tampoco el marido será su repre- } \\
\text { sentante. }\end{array}$ \\
\hline $\begin{array}{l}\text { Art. } 192 \text {. Se presume la autorización del marido } \\
\text { en la compra de cosas muebles que la mujer } \\
\text { hace al contado. Se presume también la auto- } \\
\text { rización del marido en las compras al fiado de } \\
\text { objetos naturalmente destinados al consumo } \\
\text { ordinario de la familia. [...] }\end{array}$ & $\begin{array}{l}\text { Art. 5. La mujer casada, mayor de edad, como } \\
\text { tal, puede comparecer libremente en juicio, } \\
\text { y para la administración y disposición de sus } \\
\text { bienes no necesita autorización marital ni licencia } \\
\text { del juez, ni tampoco el marido será su repre- } \\
\text { sentante. }\end{array}$ \\
\hline $\begin{array}{l}\text { Art. 195. Si la mujer casada ejerce pública- } \\
\text { mente una profesión o industria cualquiera } \\
\text { (como la de directora de colegio, maestra de } \\
\text { escuela, actriz, obstetriz, posadera, nodriza), se } \\
\text { presume la autorización general del marido para } \\
\text { todos los actos y contratos concernientes a su } \\
\text { profesión o industria, mientras no intervenga } \\
\text { reclamación o protesta de su marido, notifica- } \\
\text { da de antemano al público, o especialmente al } \\
\text { que contratare con la mujer. }\end{array}$ & $\begin{array}{l}\text { Art. 5. La mujer casada, mayor de edad, como } \\
\text { tal, puede comparecer libremente en juicio, } \\
\text { y para la administración y disposición de sus } \\
\text { bienes no necesita autorización marital ni licencia } \\
\text { del juez, ni tampoco el marido será su repre- } \\
\text { sentante. }\end{array}$ \\
\hline $\begin{array}{l}\text { Art. 204. La mujer separada de bienes no } \\
\text { necesita de la autorización del marido para los } \\
\text { actos y contratos relativos a la administración } \\
\text { y goce de los que separadamente administra. } \\
\text { Tampoco necesita la autorización del marido } \\
\text { para enajenar, a cualquier título, los bienes } \\
\text { muebles que separadamente administra. Pero } \\
\text { necesita de esta autorización, o la del juez en subsi- } \\
\text { dio, para estar en juicio aun en causas concer- } \\
\text { nientes a su administración separada, salvo en } \\
\text { los casos excepcionales del artículo } 181 \text {. }\end{array}$ & $\begin{array}{l}\text { Art. 5. La mujer casada, mayor de edad, como } \\
\text { tal, puede comparecer libremente en juicio, } \\
\text { y para la administración y disposición de sus } \\
\text { bienes no necesita autorización marital ni licencia } \\
\text { del juez, ni tampoco el marido será su repre- } \\
\text { sentante. }\end{array}$ \\
\hline
\end{tabular}




\begin{tabular}{|c|c|}
\hline Ley 57 de 1887: Código Civil & Ley 28 de 1932 \\
\hline $\begin{array}{l}\text { Art. 209. La separación de bienes, pronuncia- } \\
\text { da judicialmente por el mal estado de los ne- } \\
\text { gocios del marido, podrá terminar por decreto } \\
\text { de juez, a petición de ambos cónyuges; y sin este } \\
\text { requisito continuará legalmente la separación. }\end{array}$ & $\begin{array}{l}\text { Art. 5. La mujer casada, mayor de edad, como } \\
\text { tal, puede comparecer libremente en juicio, } \\
\text { y para la administración y disposición de sus } \\
\text { bienes no necesita autorización marital ni licencia } \\
\text { del juez, ni tampoco el marido será su repre- } \\
\text { sentante. }\end{array}$ \\
\hline $\begin{array}{l}\text { Art. } 210 \text {. El restablecimiento legal de la admi- } \\
\text { nistración del marido restituye las cosas al estado } \\
\text { anterior, como si la separación de bienes no } \\
\text { hubiese existido. Pero valdrán todos los actos } \\
\text { ejecutados legítimamente por la mujer durante } \\
\text { la separación de bienes, como si los hubiese } \\
\text { autorizado la justicia. [...] }\end{array}$ & $\begin{array}{l}\text { Art. 1. Durante el matrimonio cada uno de los } \\
\text { cónyuges tiene la libre administración y disposi- } \\
\text { ción tanto de los bienes que le pertenezcan al } \\
\text { momento de contraerse el matrimonio o que } \\
\text { hubiera aportado a él, como de los demás que } \\
\text { por cualquier causa hubiere adquirido o ad- } \\
\text { quiera }[. . .]\end{array}$ \\
\hline $\begin{array}{l}\text { Art. 211. Si a la mujer casada se hiciere una } \\
\text { donación, se dejare una herencia o legado con } \\
\text { la condición precisa de que en las cosas dona- } \\
\text { das, heredadas o legadas no tenga la administra- } \\
\text { ción del marido }[. . .]\end{array}$ & $\begin{array}{l}\text { Art. 1. Durante el matrimonio cada uno de los } \\
\text { cónyuges tiene la libre administración y disposi- } \\
\text { ción tanto de los bienes que le pertenezcan al } \\
\text { momento de contraerse el matrimonio o que } \\
\text { hubiera aportado a él, como de los demás que } \\
\text { por cualquier causa hubiere adquirido o ad- } \\
\text { quiera }[. . .]\end{array}$ \\
\hline $\begin{array}{l}\text { Art. 1791. La subrogación que se haga en } \\
\text { bienes de la mujer exige, además, autorización } \\
\text { judicial con conocimiento de causa. }\end{array}$ & $\begin{array}{l}\text { Art. 5. La mujer casada, mayor de edad, como } \\
\text { tal, puede comparecer libremente en juicio, } \\
\text { y para la administración y disposición de sus } \\
\text { bienes no necesita autorización marital ni licencia } \\
\text { del juez, ni tampoco el marido será su repre- } \\
\text { sentante. }\end{array}$ \\
\hline $\begin{array}{l}\text { Art. 1504. [...] Son también incapaces los } \\
\text { menores adultos, que no han obtenido habili- } \\
\text { tación de edad; los disipadores que se hallan } \\
\text { bajo interdicción de administrar lo suyo; las } \\
\text { mujeres casadas, y las personas jurídicas. Pero la } \\
\text { incapacidad de estas cuatro clases de personas } \\
\text { no es absoluta, y sus actos pueden tener valor } \\
\text { en ciertas circunstancias y bajo ciertos respec- } \\
\text { tos determinados por las leyes [...] }\end{array}$ & $\begin{array}{l}\text { Art. 5. La mujer casada, mayor de edad, como } \\
\text { tal, puede comparecer libremente en juicio, y para } \\
\text { la administración y disposición de sus bienes no } \\
\text { necesita autorización marital ni licencia del juez, ni } \\
\text { tampoco el marido será su representante. }\end{array}$ \\
\hline $\begin{array}{l}\text { Art. 1805. El marido es jefe de la sociedad con- } \\
\text { yugal, y como tal administra libremente los bienes } \\
\text { sociales y los de su mujer; sujeto, empero, a las } \\
\text { obligaciones que por el presente título se le } \\
\text { imponen y a las que haya contraído por las } \\
\text { capitulaciones matrimoniales. }\end{array}$ & $\begin{array}{l}\text { Art. } 1 \text {. Durante el matrimonio cada uno de los } \\
\text { cónyuges tiene la libre administración y disposi- } \\
\text { ción tanto de los bienes que le pertenezcan al mo- } \\
\text { mento de contraerse el matrimonio o que hubiera } \\
\text { aportado a él, como de los demás que por cualquier } \\
\text { causa hubiere adquirido o adquiera; [...] }\end{array}$ \\
\hline
\end{tabular}

Continúa 
Art. 1806. El marido es, respecto de terceros, dueño de los bienes sociales, como si ellos y sus bienes propios formasen un solo patrimonio, de manera que durante la sociedad, los acreedores del marido podrán perseguir tanto los bienes de este como los bienes sociales; [...] Podrán, con todo, los acreedores perseguir sus derechos sobre los bienes de la mujer [...]

Art. 1807. Toda deuda contraída por la mujer con mandato general o especial, o con autorización expresa o tácita del marido, es, respecto de terceros, deuda del marido, y por consiguiente de la sociedad; y el acreedor no podrá perseguir el pago de esta deuda sobre los bienes propios de la mujer, sino solo sobre los bienes de la sociedad y sobre los bienes propios del marido; $\sin$ perjuicio de los prevenido en el inciso $2^{\circ}$ del artículo precedente. Los contratos celebrados por el marido y la mujer de consuno, o en que la mujer se obligue solidaria o subsidiariamente con el marido no valdrán contra los bienes propios de la mujer, salvo en los casos y términos del sobredicho inciso $2^{\circ}$.

Art. 1808. La mujer por sí sola no tiene derecho alguno sobre los bienes sociales durante la sociedad. La autorización de la justicia en subsidio no produce otros efectos que los declarados en el artículo 191.

Art. 1809. Aunque la mujer, en las capitulaciones matrimoniales, renuncie a los gananciales, no por eso tendrá la facultad de percibir los frutos de sus bienes propios, los cuales se entienden concedidos al marido para soportar las cargas del matrimonio, pero con la obligación de conservar y restituir dichos bienes según después se dirá. Lo dicho deberá entenderse son perjuicio de los derechos de la mujer divorciada o separada de bienes.
Art. 2. Cada uno de los cónyuges será responsable de las deudas que personalmente contraiga, salvo las concernientes a satisfacer las ordinarias necesidades domésticas o de crianza, educación y establecimiento de los hijos comunes, respecto de las cuales responderán solidariamente ante terceros, y proporcionalmente entre sí, conforme el Código Civil.

Art. 2. Cada uno de los cónyuges será responsable de las deudas que personalmente contraiga, salvo las concernientes a satisfacer las ordinarias necesidades domésticas o de crianza, educación y establecimiento de los hijos comunes, respecto de las cuales responderán solidariamente ante terceros, y proporcionalmente entre sí, conforme el Código Civil.

Art. 3. Son nulos absolutamente entre cónyuges las donaciones irrevocables y los contratos relativos a inmuebles salvo el de mandato general.

Nota: el anterior artículo tercero fue modificado por la Corte Constitucional mediante Sentencia C-068 de febrero 10 de 1999, M. P. Alfredo Beltrán Sierra en cuanto son válidas la donación entre cónyuges y los contratos relativos a inmuebles.

Art. 1. Durante el matrimonio cada uno de los cónyuges tiene la libre administración y disposición tanto de los bienes que le pertenezcan al momento de contraerse el matrimonio o que hubiera aportado a él, como de los demás que por cualquier causa hubiere adquirido o adquiera [...]

Art. 1. Durante el matrimonio cada uno de los cónyuges tiene la libre administración y disposición tanto de los bienes que le pertenezcan al momento de contraerse el matrimonio o que hubiera aportado a él, como de los demás que por cualquier causa hubiere adquirido o adquiera [...] 


\begin{tabular}{|c|c|}
\hline Ley 57 de 1887: Código Civil & Ley 28 de 1932 \\
\hline $\begin{array}{l}\text { Art. } 1810 \text {. No se podrán enajenar ni hipote- } \\
\text { car los bienes de la mujer, que el marido esté } \\
\text { o pueda estar obligado a restituir en especie, } \\
\text { sino con voluntad de la mujer y previo decreto } \\
\text { de juez o de prefecto, con conocimiento de } \\
\text { causa. [.... }\end{array}$ & $\begin{array}{l}\text { Art. } 1 \text {. Durante el matrimonio cada uno de los } \\
\text { cónyuges tiene la libre administración y disposi- } \\
\text { ción tanto de los bienes que le pertenezcan al mo- } \\
\text { mento de contraerse el matrimonio o que hubiera } \\
\text { aportado a él, como de los demás que por cualquier } \\
\text { causa hubiere adquirido o adquiera [....] }\end{array}$ \\
\hline $\begin{array}{l}\text { Art. 1811. Para enajenar otros bienes de la mujer } \\
\text { que el marido esté o pueda estar obligado a } \\
\text { restituir en especie, bastará el consentimiento } \\
\text { de la mujer, que podrá ser suplido por el juez o } \\
\text { prefecto, cuando la mujer estuviere imposibili- } \\
\text { tada de manifestar su voluntad. }\end{array}$ & $\begin{array}{l}\text { Art. 5. La mujer casada, mayor de edad, como } \\
\text { tal, puede comparecer libremente en juicio, } \\
\text { y para la administración y disposición de sus } \\
\text { bienes no necesita autorización marital ni licencia } \\
\text { del juez, ni tampoco el marido será su repre- } \\
\text { sentante. }\end{array}$ \\
\hline $\begin{array}{l}\text { Art. } 1812 \text {. Si la mujer o sus herederos proba- } \\
\text { ren haberse enajenado, hipotecado o empe- } \\
\text { ñado alguna parte de los bienes de aquella sin } \\
\text { los requisitos prescritos en los artículos prece- } \\
\text { dentes, podrán ejercer el derecho de reivin- } \\
\text { dicación, o pedir la restitución de la prenda o } \\
\text { cancelación de la hipoteca, en los casos en que } \\
\text { por regla general se concedan estas acciones. } \\
{[\ldots . .]}\end{array}$ & $\begin{array}{l}\text { Art. 5. La mujer casada, mayor de edad, como } \\
\text { tal, puede comparecer libremente en juicio, } \\
\text { y para la administración y disposición de sus } \\
\text { bienes no necesita autorización marital ni licencia } \\
\text { del juez, ni tampoco el marido será su repre- } \\
\text { sentante. }\end{array}$ \\
\hline $\begin{array}{l}\text { Art. 1813. El marido no podrá dar en arriendo } \\
\text { los predios rústicos de la mujer por más de } \\
\text { ocho años, ni los urbanos por más de cinco; y } \\
\text { ella o sus herederos, disuelta la sociedad, esta- } \\
\text { rán obligados al cumplimiento del contrato de } \\
\text { arrendamiento que se haya estipulado por un } \\
\text { espacio de tiempo que no pase de los límites } \\
\text { aquí señalados. [...] }\end{array}$ & $\begin{array}{l}\text { Art. 5. La mujer casada, mayor de edad, como } \\
\text { tal, puede comparecer libremente en juicio, } \\
\text { y para la administración y disposición de sus } \\
\text { bienes no necesita autorización marital ni licencia } \\
\text { del juez, ni tampoco el marido será su repre- } \\
\text { sentante. }\end{array}$ \\
\hline
\end{tabular}

Nota: Los artículos transcritos en este cuadro comparativo reflejan el texto original de los artículos citados. Por lo tanto, en algunos casos la transcripción hecha aquí no concuerda con la redacción actual de los artículos del Código Civil, pues han sido modificados nuevamente o derogados por otra ley posterior a la 28 de 1932.

\section{Anexo 2. Mujeres participantes en las delegaciones que asistieron al IV Congreso Internacional Femenino de conformidad con lo publicado en el diario El Tiempo}

“España: la señora Arístegui, esposa del ministro de aquel país ante el gobierno de Colombia. Méjico: la señora Carmen de Madero, esposa del ministro de aquella nación ante el gobierno de Colombia. Chile: la señora Puga. Venezuela: señora Victoria Rosas de Barriga. Ecuador: señora Cecilia Mallarino de Monsalve. Costa Rica: señorita doña Paulina Gómez Vega. 
Cuba: señorita Maruja Puga. Panamá: señora Beatriz Arias de Cajiano, y la señora doña Claudina Múnera, quien representará el Comité Interamericano de Mujeres de aquel país. Perú: la señora de Miró Quesada, y la señora de Carvajal, también peruana. Estados Unidos: la doctora Ethel MacDonald. Las delegadas nacionales: Por el Atlántico: Las señoras Susana Olózaga de Cabo y Pepa Ubire de Lorenzana, y las señoritas María Eastman y Emilia Lopera Berrío. Bolívar: la señora de Zubiría. Boyacá: Las señoras Ofelia Uribe de Acosta y Emma Vargas Flórez de Argüelles, y las señoritas Virgilia Camacho, Alicia Ruiz Escobar, quien representará la patria chica del presidente de la república Olaya Herrera, y la señorita Zambrano Medina. Valle: las señoras doña María Lozado de Saavedra Galindo, doña Belén de Copete y doña Clara Inés Suárez de Zawadzky. Magdalena: la señora Ana Rosa de Calvo. Huila: la señora Ana Elisa Cuéllar de Guzmán. Cauca: la señora Ángela de Valencia. Santander del Norte: la señora Ana María Vega Rangel, y las señoritas Ilva Camacho, Toscano Canal y Jaime Parra. La única delegación que no nos fue posible averiguar fue la de Santander del Sur, que la integran tres damas de lo más saliente de la sociedad bumanguesa".

Fuente: tomado del periódico El Tiempo. "Esta noche inaugura sus sesiones el IV Congreso Internacional de Mujeres", 1930. 